\title{
PENGARUH PENERAPAN MODEL PEMBELAJARAN PROBLEM SOLVING BERBASIS MIND MAPPING TERHADAP KEMAMPUAN BERPIKIR KRITIS SISWA
}

\author{
(Studi Eksperimen pada Siswa Kelas VIII Mata Pelajaran IPS Terpadu \\ di SMP Negeri 1 Kuningan)
}

Oleh : Nita Ristiani \& lin Sunarti

\begin{abstract}
Abstrak
Kemampuan berpikir kritis mencerminkan kemampuan untuk membuat suatu penilaian yang rasional atau beralasan. Biasanya menggunakan kriteria untuk menilai suatu kualitas sesuatu, produk ide atau gagasan. Jadi, intinya adalah tatakrama berpikir yang digunakan seseorang untuk mengukur atau menilai valididtas/kebenaran sesuatu seperti pernyataan, kisah, argument, penelitian dan lain-lain.

Penelitian ini bertujuan untuk mengetahui perbedaan kemampuan berfikir kritis antara kelas yang menggunakan Model pembelajaran PBL berbasis Mind Mapping dengan kelas yang menggunakan Metode Ceramah, dan untuk mengetahui peningkatan kemampuan berfikir kritis antara kelas yang menggunakan Model pembelajaran PBL berbasis Mind Mapping dengan kelas yang menggunakan Metode Ceramah.

Metode penelitian yang digunakan adalah metode eksperimen, dengan subyek penelitian siswa kelas VIII A dan kelas VIII B dengan jumlah 80 siswa. Dengan tehnik pengumpulan data melalui tes.

Hasil penelitian menunjukkan bahwa nilai rata-rata kelas ekserimen dengan menggunakan model pembelajaran Problem Solving berbasis Mind Mapping sebesar 75,75 sementara untuk kelas kontrol dengan metode pembelajaran ceramah 65,87. Dengan pengujian kesamaan dua rata-rata (uji t) dari hasil postest diperoleh $t_{\text {hitung }}=5,1050>t_{\text {tabel }}=1,9908>t_{\text {tabel }}$ pada taraf signifikan 0,05 dengan derajat kebebasan $\mathrm{dk}=78$, sehingga dapat disimpulkan bahwa terdapat perbedaan hasil postest antara kelas eksperimen dengan menggunakan model pembelajaran Problem Solving berbasis Mind Mapping dengan kelas kontrol yang menggunakan metode pembelajaran ceramah.

Selanjutnya hasil uji $\mathrm{N}$-gain menunjukkan $\mathrm{t}$ hitung $(3,2508)>\mathrm{t}$ tabel $(1,9908)$. dengan demikian dapat disimpulkan bahwa terdapat perbedaan (gain) kemampuan berpikir kritis kelas ekperimen dengan menggunakan model pembelajaran Problem Solving berbasis Mind Mapping dengan kelas kontrol yang menggunakan metode pembelajaran ceramah.

Berdasarkan hasil penelitian yang telah dipaparkan diatas, model pembelajaran Problem Solving berbasis Mind Mapping lebih efektif dalam meningkatkan kemampuan berpikir kritis peserta didik dibandingkan dengan metode pembelajaran ceramah.
\end{abstract}

\section{Pendahuluan}

Pendidikan memiliki peranan yang sangat penting bagi manusia, baik itu pendidikan secara formal maupun informal, karena pendidikan mempunyai tanggung jawab yang besar untuk mencerdaskan anak bangsa dan menyiapkan sumber daya manusia yang baik. Pendidikan diharapkan mampu menghasilkan output yang berkualitas.

Untuk mewujudkan tujuan pendidikan tersebut, salah satu upaya yang dapat dilakukan yaitu guru harus mencoba mencari pola pembelajaran yang menarik, menyenangkan dan membuat siswa menjadi bagian dari pelajaran, agar materi yang disampaikan mudah dimengerti dan dapat meningkatkan kemampuan berpikir kritis siswa.

Kemampuan berpikir merupakan kegiatan penalaran yang reflektif, kritis, dan kreatif yang berorientasi pada suatu proses intelektual yang melibatkan pembentukan konsep, aplikasi, analisis, menilai informasi yang terkumpul atau dihasilkan melalui pengamatan , pengalaman, refleksi, pentaakulan, atau komunikasi sebagai 
landasan kepada satu keyakinan (kepercayaan) dan tindakan (Iskandar, 2009: 86).

Peserta didik seringkali hanya menunjukan penguasaan salah satu aspek pembelajaran pada tataran keterampilan berpikir tingkat rendah yaitu mengingat/menghafal. Kemampuan berpikir kritis adalah salah satu kompetensi yang harus dicapai oleh siswa dalam mengkontruksi pengetahuannya, karena dengan berpikir kritis siswa dapat dengan cepat mengolah informasi keilmuan yang ditransfer dari gurunya. Namun pada kenyataan nya pembelajaran hanya terfokus pada paradigma penerusan informasi dari guru kepada siswa. Hal ini terbukti dengan hasil belajar siswa yang sering kali belum mencapai standar kompetensi minimum.

Berdasarkan hasil tes terhadap kemampuan berfikir kritis siswa dalam mata pelajaran IPS di kelas VIII, SMP N 1 Kuningan, diperolah hasil sebagai berikut

Tabel 1

Nilai Rata-rata Hasil Tes Kemampuan Berfikir Kritis Siswa Kelas VIII SMP Negeri 1 Kabupaten Kuningan Tahun Ajaran 2015/2016

\begin{tabular}{|c|c|c|c|c|}
\hline No. & Kelas & Rata-rata Nilai Tes & KKM & Keterangan \\
\hline 1 & A & 63,6 & 75 & $\begin{array}{c}\text { Tidak } \\
\text { Tuntas }\end{array}$ \\
\hline 2 & B & 63,6 & 75 & Tuntas \\
\hline 3 & C & 63,6 & 75 & $\begin{array}{c}\text { Tidak } \\
\text { Tuntas }\end{array}$ \\
\hline 4 & D & 86,1 & 75 & Tuntas \\
\hline 5 & E & 63,6 & 75 & Tidak \\
\hline 6 & F & 78,1 & 75 & Tuntas \\
\hline
\end{tabular}

Tabel 1. diatas menunjukkan bahwa kemampuan berpikir kritis siswa VIII SMP Negeri 1 Kuningan semester ganap tahun pelajaran 2015-2016 masih rendah, dan masih butuh peningkatan. Hasil pengamatan dan penelitian dengan menggunakan rubrik kemampuan berpikir kritis siswa di kelas VIII SMP Negeri 1 Kuningan menunjukan belum terbentuk secara maksimal, khususnya dalam mengembangkan siswa dalam merumuskan suatu masalah, berhipotesis, menginterpretasi pernyataan, memberi alasan dari suatu kejadian dan memberi solusi yang tepat dari suatu masalah.

Banyak faktor yang bisa mempengaruhi kemampuan berfikir kritis siswa, salah satunya dengan dengan menggunakan model pembelajaran Problem solving berbasis Mind Mapping. Menurut Wina Sanjaya
(2010: 214) bahwa "Problem solving diartikan sebagai rangkaian aktivitas pembelajaran yang menekankan kepada proses penyelesaian masalah yang dihadapi secara ilmiah".

Sejalan dengan model pembelajaran Problem solving, Menurut Tony Buzan dan Barry (2012: 6) bahwa "Mind Mapping dapat membantu menyelesaikan masalah".

Selain itu Menurut Tony Buzan,(2007:4) bahwa Mind Mapping adalah : "Suatu pembelajaran yang melibatkan aktivitas seluruh siswa dengan cara mencatat yang menyenangkan, cara mudah menyerap dan mengeluarkan informasi serta ide baru dalam otak. Sebagai cara mencatat kreatif dan efektif, cara mudah memasukan dan mengeluarkan informasi dalam otak, dengan menggunakan warna, symbol, kata, 
garis lengkung, dan gambar yang sesuai dengan kerja otak".

Dengan model pembelajaran Problem Solving berbasis Mind Mapping dikelas dapat membuat peserta didik bekerja sama secara kelompok, saling mengungkapkan gagasan untuk memecahkan suatu permasalahan yang akan melatih kemampuan peserta didik untuk berpikir kreatif dan menuangkannya dalam konsep Mind Mapping.

Berdasarkan latar belakang diatas mendorong peneliti untuk melakukan penelitian dengan judul "Pengaruh Penerapan Model Problem Solving Berbasis Mind Mapping Terhadap Kemampuan Berpikir Kritis Siswa (Studi Eksperimen pada Siswa Kelas VIII Mata Pelajaran IPS Terpadu di SMP Negeri 1 Kuningan)"

\section{Masalah Penelitian}

a. Apakah terdapat perbedaan kemampuan berpikir kritis dalam pengukuran akhir (postest) antara siswa kelas eksperimen yang mendapatkan model pembelajaran Problem solving berbasis Mind Mapping dibandingkan dengan siswa kelas kontrol yang mendapatkan metode pembelajaran ceramah?

b. Apakah terdapat perbedaan peningkatan (gain) kemampuan berpikir kritis siswa antara kelas eksperimen yang mendapatkan model pembelajaran Problem solving berbasis Mind Mapping dibandingkan dengan siswa kelas kontrol yang mendapatkan metode pembelajaran ceramah?

3. Tujuan Penelitian

a. Untuk mendeskripsikan perbedaan kemampuan berpikir kritis dalam pengukuran akhir (postest) antara siswa kelas eksperimen yang mendapatkan model pembelajaran Problem solving berbasis Mind Mapping dibandingkan dengan siswa kelas kontrol yang mendapatkan metode pembelajaran ceramah.

b. Untuk mendeskripsikan perbedaan peningkatan (gain) kemampuan berpikir kritis siswa antara kelas eksperimen yang mendapatkan model pembelajaran Problem solving berbasis Mind Mapping dibandingkan dengan siswa kelas kontrol yang mendapatkan metode pembelajaran ceramah.

\section{Kerangka Teoritis}

a. Berpikir Kritis

Berpikir kritis berarti bahwa proses mental yang efektif dan handal digunakan dalam mengejar pengetahuan yang relevan dan benar tentang dunia. Proses mental yang masuk akal, reflektif, dan bertanggungjawab, membantu kita memutuskan apa yang harus diyakini atau dilakukan. Seseorang yang berpikir kritis dapat mengajukan pertanyaan yang memadai, mengumpulkan informasi yang relevan, secara efisien dan kreatif memilah-milah informasi ini, melakukan penalaran secara logis dari informasi ini,dan sampai pada konklusi yang handal dan dapat dipercaya tentang dunia, yang memampukan orang untuk hidup dan bertindak secara sukses didalamnya.

Berfikir adalah suatu keaktifan pribadi manusia yang mengakibatkan penemuan yang terarah pada suatu tujuan. Ciri-ciri berfikir yang terutama dari berpikir adalah adanya abstraksi. Abstraksi dalam hal ini berarti anggapan lepasnya kualitas atau relasi dari benda-benda, kejadian-kejadian dan situasi-situasi yang ada mula-mula dihadapi sebagai kenyataan (Ngalim Purwanto, 1990: 43).

Menurut Wina sanjaya (2011: 230) "kemampuan berpikir memerlukan kemampuan mengingat dan memahami, oleh sebab itu kemampuan mengingat adalah bagian terpenting dalam mengembangkan kemampuan berpikir". Orang yang memiliki kemampuan mengingat dan memahami belum tentu dia memiliki kemampuan dalam berpikirnya. Sebaliknya kemampuan berpikir seseorang itu sudah pasti diikuti oleh kemampuan mengingat dan memahami. Hal tersebut seperti yang dikemukakan Peter Reason (Wina Sanjaya, 2011: 231) bahwa 
"berpikir tidak mungkin terjadi tanpa adanya memori".

Berpikir menyebabkan seseorang harus bergerak hingga di luar informasi yang didengarnya. Misalnya kemampuan berpikir seseorang untuk menemukan solusi baru dari suatu persoalan yang dihadapi. Plato beranggapan bahwa berpikir itu adalah berbicara dalam hati. Sehubungan dengan pendapat Plato ini adalah pendapat yang ideasional. Pada pendapat yang akhir itu dikemukakan dua kenyataan, yaitu :

a. bahwa berpikir itu adalah aktivitas, jadi subjek yang berpikir aktif, dan

b. bahwa aktivitas itu sifatnya ideasional, jadi bukan sensoris dan bukan motoris, walaupun dapat disertai oleh kedua hal itu; berpikir itu mempergunakan abstraksi-abstraksi atau "ideas".

Selanjutnya ada pendapat yang lebih menekankan kepada tujuan berpikir itu, yaitu yang mengatakan bahwa berpikir itu, yaitu yang mengatakan bahwa berpikir itu adalah "meletakan hubungan antara bagianbagian pengetahuan kita" (Bigot dkk., 1950: 103). Bagian-bagian pengetahuan kita yaitu segala sesuatu yang telah kita miliki, yang berupa pengertianpengertian dan dalam batas tertentu juga tanggapan-tanggapan. Berpikir adalah proses yang dinamis yang dapat dilukiskan menurut proses atau jalannya. Proses atau jalannya berpikir itu pada pokoknya ada tiga langkah, yaitu : 1) pembentukan pengertian, 2) pembentukan pendapat, dan 3) penarikan kesimpulan.

Kemampuan berpikir memerlukan kemampuan mengingat dan memahami, oleh sebab itu kemampuan mengingat adalah bagian terpenting dalam mengembangkan kemampuan berpikir. Artinya, belum tentu seseorang yang memiliki kemampuan mengingat dan memahami memiliki kemampuan juga dalam berpikir. Sebaliknya, kemampuan berpikir seseorang sudah pasti diikuti oleh kemampuan mengingat dan memahami.

Berpikir kritis dapat dipandang sebagai kemampuan berpikir siswa untuk membandingkan dua atau lebih informasi yang dimilik. Bila terdapat perbedaan atau persamaan, maka ia akan mengajukan pertanyaan atau komentar dengan tujuan untuk mendapatkan penjelasan. Menurut Ennis (2010: 143) berpikir kritis adalalah : "cara berpikir reflktif yang masuk akal atau berdasarkan nalar yang difokuskan untuk menentukan apa yang harus diyakini dan dilakukan".

Kemampuan berpikir kritis mencerminkan kemampuan untuk membuat suatu penilaian yang rasional atau beralasan. Biasanya menggunakan kriteria untuk menilai suatu kualitas sesuatu, produk idea tau gagasan. Jadi, intinya adalah tatakrama berpikir yang digunakan seseorang untuk mengukur atau menilai valididtas/kebenaran sesuatu seperti pernyataan , kisah, argument, penelitian dan lain-lain.

Berpikir reflektif. Dewey menekankan langkah-langkah yang penting dalam berfikir reflketif, yaitu: keadaan keragu-raguan, kebingungan atau adanya kesulitan yang disadari terjadi dalam pikirannya, kemudian diteruskan dengan usaha mencari, menyelidiki, untuk mendapatkan bahan atau informasi guna mengatasi keraguraguan dan kesulitan yang disadarinya itu.

Konsep Dewey (2010: 143) tentang berpikir itu menjadi dasar untuk pemecahan masalah adalah sebagai berikut:

a) adanya kesulitan yang dirasakan atau kesadaran akan adanya masalah;

b) masalah itu diperjelas dan dibatasi;

c) mencari informasi atau data dan kemudian data itu diorganisasikan;

d) mencari hubungan-hubungan untuk merumuskna hipotesis-hipotesis, kemudian hipotesis-hipotesis itu dinilai, diuji agar dapat dietentukan untuk diterima atau ditolak;

e) penerapan pemecahan terhadap masalah yang dihadapi sekaligus berlaku sebagai pengujian kebenaran pemecahan tersebut untuk dapat sampai pada kesimpulan. 
Dari pendapat para ahli diatas dapat disimpulkan bahwa berpikir merupakan proses mental yang dilakukaan seseorang dengan menghubungkan pengetahuanpengetahuan yang dimilikinya. Berpikir dibedakan menjadi dua yaitu berpikir tingkat rendah dan berpikir tingkat tinggi. Dalam berpikir tingkat rendah apa dapat menghasilkan ide, gagasan dan pengetahuan. Sedangkan dalam berpikir tingkat tinggi dapat menghasilkan suatu pemecahan masalah dan pengambilan keputusan.

Dalam takstonom bloom, berpikir tingkat rendah hanya mencakup tiga aspek yaitu pengetahuan (C1), pemahaman (C2), dan penerapan (C3), dimana proses berpikir tingkat rendah hanya melibatkan kemampuan siswa dalam menerima informasi kemudian informasi itu diucapkan kembali. Sedangkan berpikir tingkat tinggi mencakup aspek analisis (C4), Sintetis (C5), dan Evaluasi (C6). Dimana proses berpikir tingkat tinggi mencakup pemecahan masalah, pengambilan keputusan, berpikir kritis dan berpikir kreatif.

\section{b. Berfikir Konvergen dan Berfikir Divergen}

Dewey dan Wertheimer (Slameto, 2010: 144) memandang berfikir sebagai proses, maka Guilford berpendapat bahwa ada tiga komponen pokok dalam berpikir yaitu: pengerjaan (operations), isi (contens) dan hasil (product). Komponen pengerjaan terdiri dari :

1) Kognisi, berarti penemuan atau penemuan kembali, atau pengenalan kembali;

2) Meningkat, berarti menyimpan apa aja yang telah dikenal;

3) Berpikir divergen, berarti berpikir dalam arah yang berbeda-beda, akan diperoleh jawaban-jawaban unik yang berbeda-beda tetapi benar;

4) Berfikir konvergen, berarti berpikir menuju satu arah yang benar atau satu jawaban yang paling tepat atau satu pemecahan dari suatu masalah;

5) Evaluasi, berarti keputusan mengenai kebaikan, kebenaran atau kesesuaian apa yang kita ketahui, kita ingat, dan apa yang kita hasilkan dalam berpikir produktif.

Istilah-istilah lain yang sama pengertiannya dengan berpikir konvergen ialah berpikir logis (logical thinking); berpikir kritis (critical thinking) dan reasoning.

\section{c.Model Pembelajaran Problem} solving berbasis Mind Mapping

Model pembelajaran Problem solving berbasis Mind Mapping. Menurut Wina Sanjaya (2010: 214) bahwa "Problem solving diartikan sebagai rangkaian aktivitas pembelajaran yang menekankan kepada proses penyelesaian masalah yang dihadapi secara ilmiah".

Sejalan dengan model pembelajaran Problem solving, Menurut Tony Buzan dan Barry (2012: 6) bahwa "Mind Mapping dapat membantu menyelesaikan masalah". Selain itu Menurut Tony Buzan,(2007:4) bahwa Mind Mapping adalah : "suatu pembelajaran yang melibatkan aktivitas seluruh siswa dengan cara mencatat yang menyenangkan, cara mudah menyerap dan mengeluarkan informasi serta ide baru dalam otak. Sebagai cara mencatat kreatif dan efektif, cara mudah memasukan dan mengeluarkan informasi dalam otak, dengan menggunakan warna, symbol, kata, garis lengkung, dan gambar yang sesuai dengan kerja otak".

Dengan model pembelajaran Problem Solving berbasis Mind Mapping dikelas dapat membuat peserta didik bekerja sama secara kelompok, saling mengungkapkan gagasan untuk memecahkan suatu permasalahan yang akan melatih kemampuan peserta didik untuk berpikir kritis dan menuangkannya dalam konsep Mind Mapping.

a. Karakteristik Mind Mapping

Menurut Bermawi Munthe (2009:

18) karakteristik Mind Mapping adalah sebagai berikut :

a) Biasanya berstruktur hierarkis dengan lebih inklusif. Dalam struktur tersebut, konsep-konsep general berada di bagian atas, kemudian kurang inklusif, dan diikuti dengan 
konsep-konsep khusus yang diletakkan di bagian peta.

b) Kata-kata yang menghubungkan selalu ada di atas garis-garis yang menghubungkan konsepkonsep.

c) Mind map mengalir dari atas ke bawah halaman, Tanda panah digunakan untuk menunjukan arah hubungan.

d) Sebuah mind map merupakan reperensi atau gambaran seseorang tentang sebuah masalah (mata pelajaran, topik persoalan).

e) Kekuatan mind map berasal dari inter-koneksi antarkonsep.

f) Perasaan seseorang mungkin terekspresikan ke dalam sebuah min map dengan memasukan konsep-konsep yang bernada empati, atau perasaan tidak suka,atau perasaan stress terhadap sebuah konsep, seperti senang, takut, marah, tertekan dan sebagainya.

Kesimpulanya karakteristik Mind mapping ini berada pada membedakan kata-kata atau gagasan, menggunakan dengan warna dan symbol. Mind Mapping pada umumnya mengambil format hirarki atau cabang pohon, dengan ide-ide bercabang menjadi subbagian mereka. Peta pemikiran memungkinkan kreativitas yang lebih besar saat merekam ide-ide dan informasi, serta memungkinkan catatan untuk mengasosiasikan kata dengan representasi visual.

\section{d. Langkah-langkah dalam Membuat Mind Mapping \\ Pembuatan Mind Mapping} dilakukan dengan membuat suatu sajian visual atau suatu diagram tentang bagaimana ide-ide penting atau suatu topik tertentu dihubungkan satu sama lain.

Adapaun sarana dan prasarana untuk membuat Mind Mapping yang dikemukakan oleh Buzan (2012: 14) adalah sebagai berikut :

a) Kertas kosong tak bergaris.

b) Pena dan pensil warna. c) Otak

d) Imajinasi

Berdasarkan pendapat diatas, dapatlah dikemukakan langkah-langkah dalam membuat Mind Mapping secara rinci sebagai berikut :

a) Mulai dengan Topik di Tengahtengah Halaman

Awali dengan menuliskan tema pokok atau ide utama ditengahtengah halaman atau apat juga menulis tema pokok di bagian atas, di pinggir sesuai proses kerja otak. Ini mendorong untuk mendefinisikan gagasan inti subjek yang berada ditengah atau merupakan konsep utama dari materi yang di Mind Mapping kan. Sub-sub tema tersebut dapat dihubungkan dengan tema pokok me makai garis, seperti cabang-cabang.

b) Gunakan gambar (simbol) untuk ide utama.

Gambar pada ide utama harus disesuaikan dengan tema atau konsep materi. Gambar (simbol) merupakan pendukung untuk menjelaskan banyak kata menjadi suatu gambar yang sederhana.

c) Gunakan berbagai warna

Warna akan memberikan daya ingat akan konsep-konsep dalam Mind Mapping. Akan tetapi jika tidak mempunyai alat warna atau komputer untuk mewarnai maka akan mempengaruhi dalam pembuatan Mind Mapping karena cukup dengan pensil atau pulpen dan kertas juga dapat membuat peta pikiran sebagai alat berpikir, jadi tujuannya pun masih dapat tercapai.

d) Hubungkan cabang-cabang utama

Hal yang harus diperhatikan dalam langkah ini yaitu megurutkan cabang-cabang dalam suatu konsep yang 
dijabarkan yaitu mengurutkan dari yang inklusif ke yang kurang inklusif, maksudnnya dari mulai ide utama lalu menghubungkan pada cabangcabang utama yang merupakan sub judul suatu materi, setela itu hubungkan pada cabangcabang pendukung dan terakhir hubungkan dengan poin-poin penting. Hal ini dilakukan karena otak bekerja menurut asosiasi, otak senang mengaitkan dua (tiga atau empat hal sekaligus. Bila kita menghubungkan cabangcabang, kita akan lebih mudah mengerti dan mengingat.

e) Buatlah garis hubung

Langkah ini berkaitan dengan pengaturan garis, garis yang digunakan dapat menggunakan garis lurus dan garis yang melengkung. Dalam pengaturan garis juga harus memperhatikan ketebalan pada teks dan garis yaitu ide utama lebih tebal dari pada cabang utama, cabang utama lebih tebal dari pada cabang pendukung, dan cabang pendukung lebih tebal dari pada poin-poin.

f) Gunakan kata kunci untuk setiap garis dan gunakan gambar

Dengan penggunaan kata kunci dan gambar yang menyangkut konsep tersebut akan memudahkan daya ingat akan konsep yang dipelajari. Dapat simpulkan bahwa dengan adanya Mind Mapping akan memudahkan siswa daalam mencatat secara tradisional yang berhalaman-halaman sekarang adapat disajikan dalam satu gambar yang menarik dan bermakna serta siswa tidak harus membalikbalikan kertas untuk membaca materi dan memahami materi tersebut. Selain itu siswa dapat dengan mudah memahami materi IPS ekonomi yang memiliki banyak materi yang harus dihapalkan dan dipahami karena adanya posisi, warna, atau gambar dalam peta pikiran yang dibuat oleh siswa secara kreatif.

\section{e. Manfaat Mind Mapping}

Agar terdorong

untuk menggunkana peta pikiran, kita perlu mengetahui manfaat dari peta pikiran yang diantaranya adalah menyenangkan, imajinasi dan kreativitas kita tidak terbatas.

Menurut Tony Buzan dan Barry (2012: 6) Mind map membantu kita dalam hal :

a) Merencana.

b) Berkomunikasi.

c) Menjadi lebih keatif.

d) Menghemat waktu.

e) Menyelesaikan masalah.

f) Memusatkan perhatian.

g) Menyusun dan menjelaskan pikiran0pikiran.

h) Mengingat dengan lebih baik.

i) Belajar lebih cepat dan efesien.

Sedangkan menurut David $N$. Hyerle (2011: 162) menjelaskan Ada 3 (tiga) manfaat Mind Mapping, yaitu :

1) Peta Pemikiran membantu siswa untuk memeroses informasi secara aktif.

Penggunaan peta menciptakan pertanyaan langsung dan khusus. Di kelas sekolah menengah, tantangan yang konstan adalah pelibatan maksimal. Bahkan dengan digunakan di bentuk mereka yang paling terbatas, Peta Pemikiran memastikaan delapan pertanyaan "yang sudah siap". Pertanyaan itu dikaitkan dengan delapan keterampilan berpikir. Peta Pemikiran membangun jembatan dari pengetahuan konkret ke konsep abstrak.

2) Peta Pemikiran menjembatani perbedaan antara fakta konkret dan pemikiran abstrak sebagai kebutuhan perkembangan remaja.

Peta Pemikiran memberikan siswa struktur yang fleksibel untuk menciptakan visi pengetahuan mereka sendiri ketika mereka 
menciptakan peta mereka. Karena tidak ada peta yang lengkap, fleksibilitas ini memaastikan bahwa siswa di semua tingkat pertumbuhan bias secara konsisten ditantang di dalam pemikiran mereka, membangun dari informasi konkret ke informasi konsep.

3) Peta Pemikiran bekerja sebagai perangkat pengajaran, pembelajaran, dan penilaian.

Konfigurasi yang fleksibel dari peta ini memungkinkan semua guru untuk berperan serta untuk menciptakan penerapan di dalam dan di lintas materi pelajaran. Siswa bias secara sukses menggunakan peta sebagai pembelajar dan pemikir mandiri untuk mengelola pemikiran mereka guna membuat catatan, pada tes formatif dan sumatif. Banyak dari guru saya yang secara berkala meminta siswa mereka untuk menciptakan satu atau beberapa Peta pemikiran guna menunjukan apa yang mereka ketahui ketika mereka mengembnagkan ide, membentuk esai, atau merespon pertanyaan khas yang muncul di akhir sebagian besar bab.

\section{Penelitian Terdahulu}

\section{Sumber : Tia Ristiasari, Bambang} Priyono dan Sri Sukaesih

Penelitian ini bertujuan untuk mengetahui apakah model pembelajaran problem solving dengan Mind mapping berpengaruh terhadap kemampuan berpikir kritis siswa kelas VII SMP N 6 Temanggung. Penelitian eksperimental ini menggunakan desain Nonequivalent Control Group Design. Subyek yang digunakan adalah VIIG sebagai kelas eksperimen yaitu kelas yang menerapkan model pembelajaran Problem solving dengan Mind dan kelas VIIE sebagai kelas kontrol yaitu kelas yang pembelajarannya menggunakan metode ceramah dan diskusi biasa.

Hasil penelitian meliputi peningkatan tes kemampuan berpikir kritis siswa kelas eksperimen sebesar 0,40 (sedang) sedangkan untuk kelas kontrol sebesar 0,23 (rendah). Ketuntasan klasikal siswa kelas eksperimen adalah sebesar 71,87\%, sedangkan pada kelas kontrol ketuntasan klasikal yang dicapai hanya sebesar $40 \%$

Hasil uji test menunjukkan bahwa kemampuan berpikir kritis kelas eksperimen berbeda signifikan dengan kelas kontrol. Kesimpulan dari penelitian inibahwa penerapan model pembelajaran problem solving dengan mind mapping berpengaruh terhadap kemampuan berpikir kritis siswa di SMP Negeri 6 Temanggung.

\section{Kerangka Pemikiran}

Seorang peserta didik dikatakan mampu berfikir kritis apabila ia mempunyai mental yang efektif dan handal digunakan dalam mengejar pengetahuan yang relevan dan benar tentang dunia. Proses mental yang masuk akal, reflektif, dan bertanggungjawab, membantu kita memutuskan apa yang harus diyakini atau dilakukan. Seorang peserta didik yang berpikir kritis dapat mengajukan pertanyaan yang memadai, mengumpulkan informasi yang relevan, secara efisien dan kreatif memilahmilah informasi, mampu memecahkan permasalahan, melakukan penalaran secara logis dari informasi,dan sampai pada konklusi yang handal dan dapat dipercaya. Salah satu alternative yang tepat agar siswa dapat mempunyai kemampuan berfikir kritis yang baik dalam materi pelajaran yaitu menerapkan model Problem solving berbasis Mind Mapping.

Pembelajaran berbasis masalah adalah rangkaian aktivitas pembelajaran yang menekankan kepada proses penyelesaian masalah yang dihadapi secara ilmiah. Mind Mapping (Peta Pikiran) adalah cara mencatat yang menyenangkan, cara mudah menyerap dan mengeluarkan informasi serta ide baru dalam otak. Dimana Mind Mapping merupakan salah satu pembelajaran aktif yang mengkondisikan siswa terlibat aktif dalam proses pembelajaran, memupuk kerjasama diantara siswa serta melatih keterampilan siswa dalam pembelajaran, memupuk kerjasama 
diantara siswa serta melatih keterampilan siswa dalam mengeluarkan berbaga ide. teknik ini memberikan kesempatan kepada siswa untuk lebih kritis dalam memikirkan sebuah konsep materi selain itu dengan teknik ini siswa lebih mudah untuk mengingat materi pembelajaran.
Dari penjelasan diatas maka penulis simpulkan bahwa pembelajaran dikelas dengan alternatif penggunaan metode Problem solving berbasis Mind mapping dapat mengembangkan kemampuan berfikir kritis siswa dan menyerap materi lebih baik.

Berdasarkan kerangka berfikir tersebut, penulis membuat pola model penelitian sebagai berikut :

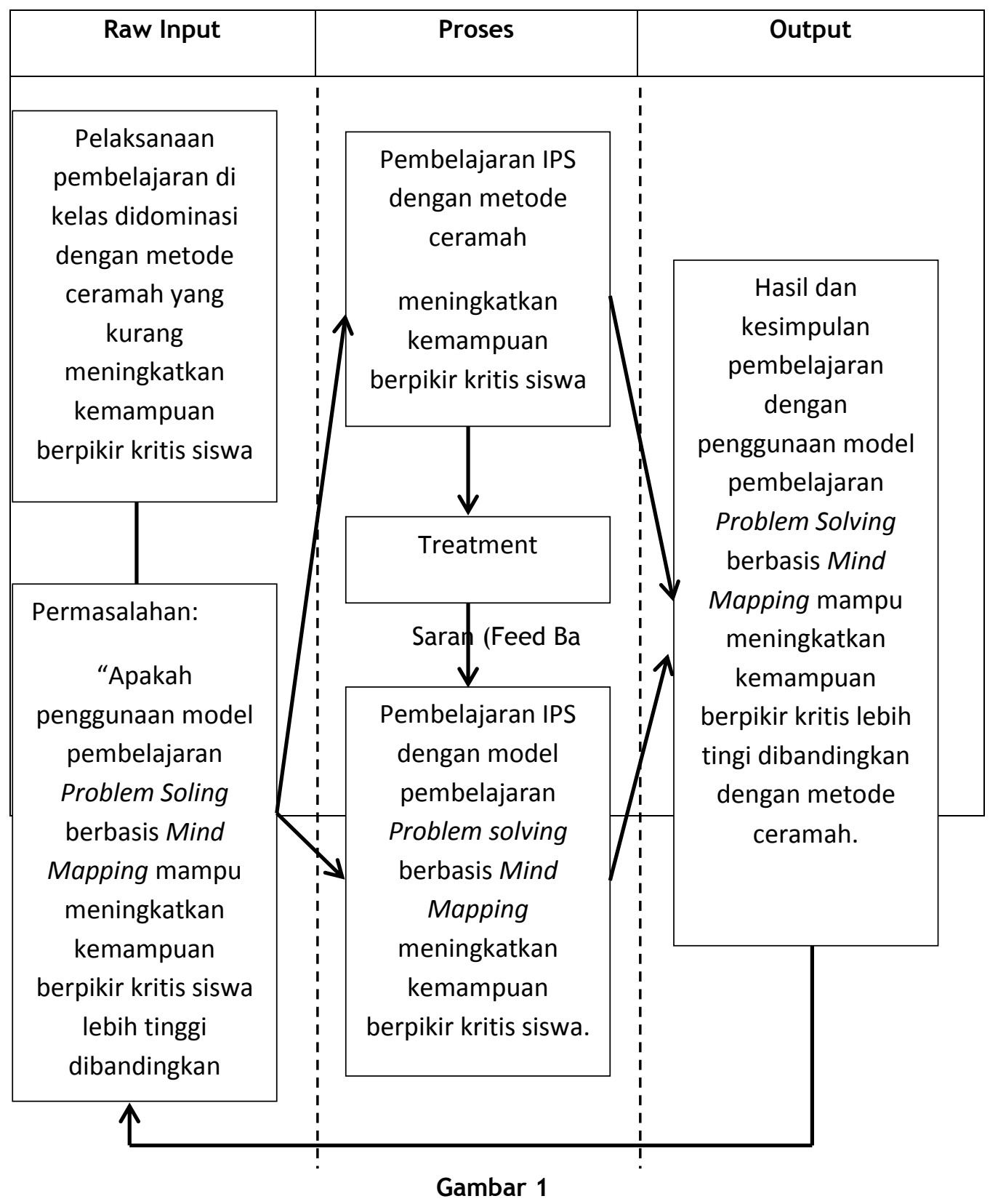

Pola Model Penelitian 


\section{Hipotesis}

Suharsimi Arikunto (2006 : 67) berpendapat bahwa hipotesis adalah suatu jawaban yang bersifat sementara terhadap permasalahan penelitian, sampai terbukti melalui data yang terkumpul.

Maka hipotesis yang akan digunakan dalam penelitian ini adalah sebagai berikut :

$$
\begin{aligned}
& \mathrm{H}_{1:} \text { Terdapat perbedaan } \\
& \text { kemampuan berpikir kritis } \\
& \text { dalam pengukuran akhir } \\
& \text { (postest) antara siswa kelas } \\
& \text { eksperimen yang menggunakan } \\
& \text { model pembelajaran Problem } \\
& \text { solving berbasis Mind Mapping } \\
& \text { lebih tinggi dibandingkan } \\
& \text { dengan siswa kelas kontrol yang } \\
& \text { menggunakan metode } \\
& \text { pembelajaran ceramah. }
\end{aligned}
$$

$\mathrm{H}_{2:}$ Terdapat perbedaan
peningkatan (gain) kemampuan
berpikir kritis siswa antara
kelas eksperimen yang
menggunakan r model
pembelajaran Problem solving
berbasis Mind Mapping lebih
tinggi dibandingkan dengan
siswa kelas kontrol yang

$$
\text { menggunakan metode }
$$$$
\text { pembelajaran ceramah. }
$$

\section{Metode penelitian}

Metode penelitian yang digunakan dalam penelitian ini adalah metode eksperimen. Menurut Sugiyono (2012:107) Metode eksperimen dapat diartikan metode penelitian yang digunakan untuk mencari pengaruh perlakuan tertentu terhadap yang lain dalam kondisi yang terkendalikan.

Jadi, metode eksperimen adalah pendekatan kuantittif yang menghubungkan sebab-akibat atau pengaruh. Dalam penelitian eksperimen peneliti menciptakan sebab, secara sengaja membuat kelompok berbeda dan kemudian mengamati akibat perbedaan itu pada variable terikat. Metode eksperimen dalam penelitian ini dilakukan dalam proses pembelajaran.

\section{a. Desain Penelitian}

Dalam desain penelitian ini kelompok eksperimem maupun kelompok kontrol akan mendapatkan tes awal (pre test) dan tes akhir (post test). Menurut Sugiyono (2012: 116) desain penelitian tersebut dapat digambarkan sebagai berikut:

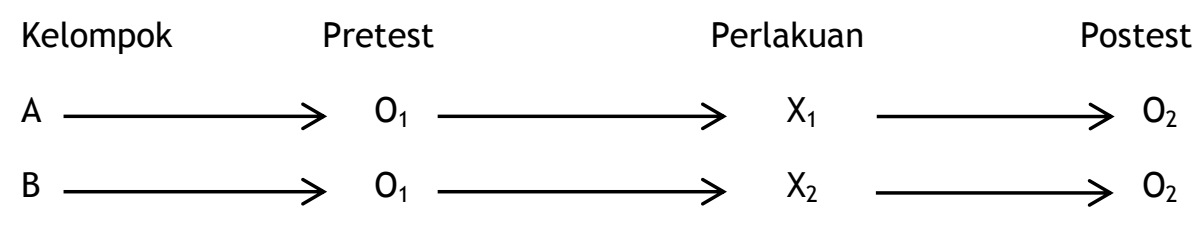

Gambar 2

Desain Penelitian

Keterangan:
A : Kelompok Eksperimen
B : Kelompok Kontrol
$\mathrm{O}_{1} \quad$ : Tes awal (pretest)
$\mathrm{O}_{2} \quad$ : Tes akhir (postest)
$\mathrm{X}_{1}$ : Kelas eksperimen dengan model pembelajaran Problem Solving beerbasis Mind Mapping
$\mathrm{X}_{2} \quad$ : Kelas kontrol dengan model pembelajaran Ceramah 


\section{b. Variabel Penelitian}

Dalam penelitian ini menggunakan dua variabel yaitu Variabel bebas atau variable independen yaitu metode Problem Solving tipe Mind Mapping (variabel $\mathrm{X}$ ) dan kemampuan berfikir kritis sebagai (variabel Y) yang merupakan variabel terikat.

\section{c. Subjek Penelitian}

Subjek dalam penelitianini adalah sswa kelas VIII SMP Negeri 1 Kuningan sebanyak 2 kelas yaitu kelas VIII A dan kelas VIII B dengan jumlah 80 siswa. Dalam hal ini, kelas VIII A dijadikan sebagai kelompok kontrol yang mendapat perlakuan dengan menggunakan metode konvensional. Sedangkan kelas VIII B dijadikan sebagai kelompok eksperimen dengan menggunakan metode Problem Solving tipe Mind Mapping .

\section{Hasil Penelitian dan Pembahasan}

\section{a) Deskripsi Perhitungan Tes Awal} (Pre test)

Untuk mengetahui kemampuan awal kelas eksperimen dan kelas kontrol, pada masing-masing kelas dilakukan pre test. Berikut disajikan dalam bentuk tabel deskripsi hasil pre test kelas yang menggunakan model pembelajaran Problem Solving berbasis Mind Mapping dan metode ceramah :

Tabel 2

Data Hasil Tes Awal (Preetest)

\begin{tabular}{|l|l|c|c|}
\hline No. & Data Penelitian & \multicolumn{2}{|c|}{ Kelompok } \\
\hline & & Eksperimen & Kontrol \\
\hline 1 & Jumlah Siswa & 40 & 40 \\
\hline 2 & Skor Tertinggi & 60 & 55 \\
\hline 3 & Skor Terendah & 10 & 20 \\
\hline 4 & Rata-rata & 39 & 36,12 \\
\hline 5 & Standar Deviasi & 11,106 & 8,434 \\
\hline
\end{tabular}

b) Deskripsi Perhitungan Tes Akhir (Postest)

Tabel 3

Data Post Test kelas eksperimen dan kelas kontrol

\begin{tabular}{|l|l|c|c|}
\hline No. & Data Penelitian & \multicolumn{2}{|c|}{ Kelompok } \\
\hline & & Eksperimen & Kontrol \\
\hline 1 & Jumlah Siswa & 40 & 40 \\
\hline 2 & Skor Tertinggi & 95 & 80 \\
\hline 3 & Skor Terendah & 60 & 50 \\
\hline 4 & Rata-rata & 75,75 & 65,87 \\
\hline 5 & Standar Deviasi & 10,655 & 7,835 \\
\hline
\end{tabular}


c)

Deskripsi N-Gain (Pretest dan Postest)

Tabel 4

Data N-Gain kelas eksperimen dan kelas kontrol

\begin{tabular}{|c|c|c|c|c|}
\hline Kelas & $\begin{array}{c}\text { Rata-rata } \\
\text { Pre test }\end{array}$ & $\begin{array}{c}\text { Rata-rata } \\
\text { Post test }\end{array}$ & N-gain & Kriteria \\
\hline Eksperimen & 39 & 75,75 & 0,59 & Sedang \\
\hline Kontrol & 36,12 & 65,87 & 0,46 & Sedang \\
\hline
\end{tabular}

Berdasarkan data nilai pre test dan post test pada kelas eksperimen, diperoleh nilai gain ternormalisasi $(N$ gain) pada kelas eksperimen sebesar 0,59 dan pada kelas kontrol sebesar 0,46 . Nilai tersebut selanjutnya di interpretasikan kedalam kriterium $\mathrm{N}$ - gain, setelah di interpretasikan diperoleh bahwa penerapan di kelas eksperimen dan kontrol sama-sama tergolong sedang.

Dari tabel diatas dapat dilihat dalam diagram dibawah ini

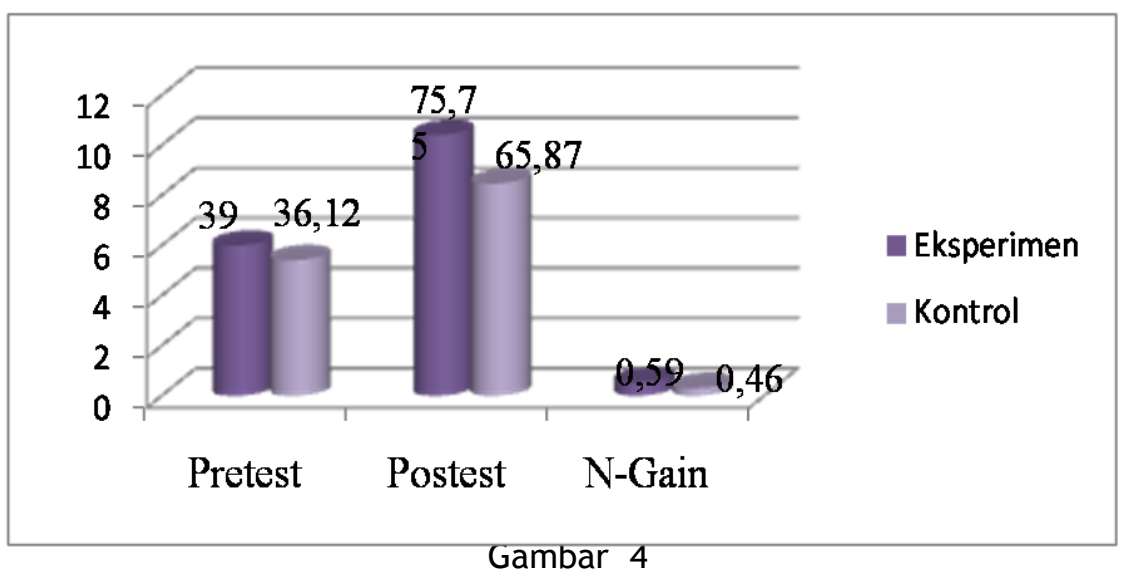

d). Persyaratan Analisis

a. Uji Normalitas

Tabel 5

Uji Normalitas Data Pre test dan Post test

\begin{tabular}{|c|c|c|c|c|}
\hline \multirow{2}{*}{ Statistik } & \multicolumn{2}{|c|}{ Kelas Kontrol } & \multicolumn{2}{c|}{ Kelas Eksperimen } \\
\cline { 2 - 5 } & Pre test & Post test & Pre test & Post test \\
\hline Rata - rata & 37,17 & 66 & 38,3 & 75,6 \\
\hline SD & 11.15 & 8,56 & 9,61 & 11,00 \\
\hline$X_{\text {hitung }}^{2}$ & -139.22 & -125.57 & -155.22 & -87.954 \\
\hline$X_{\text {tabel }}^{2}$ & 7.815 & 7.815 & 7.815 & 7.815 \\
\hline Keterangan & Normal & Normal & Normal & Normal \\
\hline
\end{tabular}


Berdasarkan

normalitas, dapat disimpulkan

data Pre test dan Post test baik kelas kontrol dan kelas eksperimen memiliki nilai yang berdistribusi normal.

\section{b. Uji Homogenitas}

Tabel 6

Hasil Uji Homogenitas Data Pre test dan Post test

\begin{tabular}{|c|c|c|c|c|}
\hline \multirow{2}{*}{ Statistik } & \multicolumn{2}{|c|}{ Pre test } & \multicolumn{2}{c|}{ Post test } \\
\cline { 2 - 4 } & $\begin{array}{c}\text { Kelas } \\
\text { Eksperimen }\end{array}$ & Kelas Kontrol & $\begin{array}{c}\text { Kelas } \\
\text { Eksperimen }\end{array}$ & Kelas Kontrol \\
\hline Varians & 92,35 & 124,32 & 121 & 73,27 \\
\hline$F_{\text {hitung }}$ & 1.3461 & 1,6514 \\
\hline$F_{\text {tabel }}$ & 1,7044 & 4044 \\
\hline $\mathrm{n} 1$ & 40 & 40 \\
\hline $\mathrm{n} 2$ & 40 & Homogen \\
\hline Keterangan & Homogen & \multicolumn{2}{c|}{1,704} \\
\hline
\end{tabular}

Dari hasil perhitungan didapat data skor tes kedua kelompok homogen.

c. Uji Hipotesis

a) Uji Kemampuan Tes Awal

Tabel 7

Uji Kemampuan Tes Awal (Pre Test)

\begin{tabular}{|c|c|c|c|c|c|c|}
\hline Kelas & $\mathbf{N}$ & $\begin{array}{c}\text { Rata- } \\
\text { rata }\end{array}$ & Varians & $t_{\text {hitung }}$ & $\boldsymbol{t}_{\text {tabel }}$ & Keterangan \\
\hline Eksperimen & 40 & 38,3 & 92,35 & & & \\
\hline
\end{tabular}

Berdasarkan tabel 12 diatas menunjukan bahwa pada taraf kepercayaan $t$ hitung $=1,5694$, sedangkan $t_{\text {tabel }}=1,9908$ atau $t_{\text {hitung }}>t_{\text {tabel }}$. Hal ini dapat disimpulkan bahwa, kedua kelas sebelum diberikan perlakuan tidak berbeda kemampuan berpikir kritis peserta didik. jadi tidak terdapat perbedaan kemampuan berpikir kritis antara kelas yang menggunakan model pembelajaran Problem Solving berbasis Mind Mapping dengan kelas yang menggunakan metode pembelajaran ceramah. Sehingga kedua kelas tersebut bisa dilanjutkan untuk penelitian selanjutnya. 
b) Uji Kemampuan Tes Akhir (Postest)

Tabel 8

Uji Hipotesis Tes Akhir (Post Test)

\begin{tabular}{|c|r|r|c|c|c|c|}
\hline Kelas & $\mathbf{N}$ & $\begin{array}{c}\text { Rata- } \\
\text { rata }\end{array}$ & Varians & $\boldsymbol{t}_{\text {hitung }}$ & $\boldsymbol{t}_{\text {tabel }}$ & Keterangan \\
\hline Eksperimen & 40 & 75,6 & 121 & 5,1050 & 1,9908 & $\begin{array}{c}\text { Terdapat } \\
\text { perbedaan } \\
\text { yang signifikan }\end{array}$ \\
\hline Kontrol & 40 & 66 & 73,27 & & & \\
\hline
\end{tabular}

Tabel diatas menunjukan bahwa $t_{\text {hitung }}(5,1050)>t_{\text {tabel }}(1,9908)$. Artinya bahwa terdapat perbedaan post test yang signifikan antara kelas yang menggunakan model pembelajaran Problem solving berbasis Mind Mapping dengan kelas yang menggunakan metode konvensional.n jadi hipotesis yang dikemukakan :Terdapat perbedaan kemampuan berpikir kritis dalam pengukuran akhir (postest) antara siswa kelas eksperimen yang menggunakan model pembelajaran Problem solving berbasis Mind Mapping lebih tinggi dibandingkan dengan siswa kelas kontrol yang menggunakan metode pembelajaran ceramah terbukti kebenarannya.

c) Uji Gain

Tabel 9

Uji N-Gain

\begin{tabular}{|c|c|c|c|c|c|c|}
\hline Kelas & $\mathbf{N}$ & $\begin{array}{c}\text { Rata }- \\
\text { rata }\end{array}$ & Varian & $\boldsymbol{t}_{\text {hitung }}$ & $\boldsymbol{t}_{\text {table }}$ & Keterangan \\
\hline Eksperimen & 40 & 0,59 & 0,021 & \multirow{2}{*}{3,2508} & 1,9908 & $\begin{array}{c}\text { Terdapat } \\
\text { perbedaan }\end{array}$ \\
\hline Kontrol & 40 & 0,46 & 0,043 & & & \\
\hline
\end{tabular}

Dari perhitungandata diatas diperoleh $\mathrm{t}_{\text {hitung }}=3,2508$ dan $\mathrm{t}$ tabel $=$ 1,9908 . Hal ini menunjukan bahwa $t_{\text {hitung }}(3,2508)>t_{\text {tabel }}(1,9908)$ maka, $H_{0}$ ditolak dan $\mathrm{H}_{1}$ diterima. Dengan demikian nilai gain kemampuan berpikir kritis peserta didik kelas eksperimen dengan menggunakan model pembelajaran Problem Solving berbasis Mind Mapping lebih tinggi dari pada kelas kontrol yang menggunakan metode pembelajaran ceramah. Jadi hipotesis yang dikemukakan yaitu :Terdapat perbedaan peningkatan (gain) kemampuan berpikir kritis siswa antara kelas eksperimen yang menggunakan model pembelajaran Problem solving berbasis Mind Mapping lebih tinggi dibandingkan dengan siswa kelas kontrol yang menggunakan metode pembelajaran ceramah terbukti kebenarannya.

d) Pembahasan Hasil Penelitian Melalui hasil pengolahan data seperti yang disajikan diatas, menunjukan bahwa hasil tes yang diberikan sebelum mendapatkan pembelajaran, nilai rata-rata kelas eksperimen dengan menggunakan model pembelajaran Problem Solving berbasis Mind Mapping sebesar 39 sementara untuk kelas kontrol dengan metode pembelajaran ceramah 36,12. Dengan pengujian kemampuan awal (pretest) diperoleh $t_{\text {hitung }}=1,5694<$ $t_{\text {tabel }}=1,9908$, sehingga dapat disimpulkan bahwa tidak terdapat perbedaan kemampuan berpikir kritis antara kelas eksperimen dengan menggunakan model pembelajaran 
Problem Solving berbasis Mind Mapping dan kelas kontrol dengan metode pembelajaran ceramah.

Berdasarkan hasil tes yang diberikan setelah mendapatkan pembelajaran, nilai rata-rata kelas ekserimen dengan menggunakan model pembelajaran Problem Solving berbasis Mind Mapping sebesar 75,75 sementara untuk kelas kontrol dengan metode pembelajaran ceramah 65,87. Dengan pengujian kesamaan dua rata-rata (uji t) dari hasil postest diperoleh $t_{\text {hitung }}>$ $t_{\text {tabel }}$ pada taraf signifikan 0,05 dengan derajat kebebasan $\mathrm{dk}=78$, diperoleh $t_{\text {hitung }}=5,1050>t_{\text {tabel }}=1,9908$, sehingga dapat disimpulkan bahwa terdapat perbedaan hasil postest antara kelas eksperimen dengan menggunakan model pembelajaran Problem Solving berbasis Mind Mapping dan kelas kontrol dengan metode pembelajaran ceramah.

Hasil uji $\mathrm{N}$ - gain, diperoleh $\mathrm{t}$ hitung $=3,2508$ dan $\mathrm{t}$ tabel $=1,9908$ atau $\mathrm{t}$ hitung $(3,2508)>t$ tabel $(1,9908)$. Dengan demikian dapat disimpulkan bahwa terdapat perbedaan peningkatan $(\mathrm{N}$ gain) kemampuan berpikir kritis kelas ekperimen dengan menggunakan model pembelajaran Problem Solving berbasis Mind Mapping dengan kelas kontrol yang menggunakan metode pembelajaran ceramah.

Berdasarkan hasil penelitian yang telah dipaparkan diatas, model pembelajaran Problem Solving berbasis Mind Mapping lebih efektif dalam meningkatkan kemampuan berpikir kritis peserta didik dibandingkan dengan metode pembelajaran ceramah, karena dalam penerapan model pembelajaran Problem Solving berbasis Mind Mapping menekankan peserta didik berpikir untuk memecahan sebuah masalah secara ilmiah. Hal ini sesuai dengan pendapat Wina Sanjaya (2010: 214) bahwa "Problem Solving diartikan sebagai rangkaian aktivitas pembelajaran yang menekankan kepada proses penyelesaian masalah yang dihadapi secara ilmiah". Sejalan dengan model pembelajaran Problem Solving, Menurut Tony Buzan dan Barry (2012: 6) bahwa "Mind Mapping dapat membantu menyelesaikan masalah". Jadi, rangkaian masalah dapat dipecahkan dan dituangan ke dalam bentuk catatan berupa peta konsep secara menyenangkan dan mudah diingat.

dengan Selama proses pembelajaran pembelajaran Problem Solving berbasis Mind Mapping terdapat kendala yang dihadapi, kendala tersebut ialah pengalokasian waktu pembelajaran. Dengan penerapan model pembelajaran Problem Solving berbasis Mind Mapping membutuhkan waktu yang lebih banyak, karena selama proses pembelajaran melibatkan peserta didik secara aktif dari awal hingga akhir pembelajaran dalam membuat Mind Mapping secara baik dan kreatif, kurangnya motivasi, keberanian dan keaktifan siswa untuk mengemukakan pendapatnya dalam memecahkan sebuah masalah yang dituangkan kedalam rancangan Mind Mapping yang telah dibuat peserta didik, peserta didik kesulitan menghubungkan konsep materi yang diajarkan dengan data dan fakta yang terdapat di lingkungan.

\section{Kesimpulan dan Saran}

Berdasarkan hasil analisis data dan pembahasan, maka dapat disimpulkan bahwa:

a) Terdapat perbedaan kemampuan berpikir kritis dalam pengukuran

akhir (postest) antara siswa kelas eksperimen yang mendapatkan model pembelajaran Problem Solving berbasis Mind Mapping dibandingkan dengan siswa kelas kontrol yang mendapatkan metode pembelajaran ceramah.

b) Terdapat perbedaan peningkatan ( $\mathrm{N}$ - gain) kemampuan berpikir kritis siswa antara kelas eksperimen yang mendapatkan model pembelajaran Problem Solving berbasis Mind Mapping dibandingkan dengan siswa 
kelas kontrol yang mendapatkan metode pembelajaran ceramah.

Model pembelajaran Problem Solving berbasis Mind Mapping lebih efektif dalam meningkatkan kemampuan berpikir kritis siswa dibandingkan dengan metode pembelajaran ceramah.

Saran :

a). Untuk menerapkan model pembelajaran problem solving berbasis mind mapping hendaknya guru menyesuaikan alokasi waktu, sehingga proses pembelajaran sesuai dengan tujuan yang telah direncanakan.

b). Ada penerapan model pembelajaran problem solving berbasis mind mapping guru membangkitkan keberanian peserta didik untuk mengemukakan pendapatnya dalam memecahkan sebuah masalah yang dituangkan kedalam rancangan Mind Mapping yang telah dibuat peserta didik.

Dalam proses pembelajaran, peserta didik diharapkan terbiasa menghubungkan konsep materi yang diajarkan dengan data dan fakta yang terdapat di lingkungan sekitar sehingga dapat melatih kemampuan berfikir kritisnya.

\section{Daftar Pustaka}

Arifin Zaenal. (2011). Evaluasi Pembelajaran. Bandung: PT. Remaja Rosdakarya

Arikunto Suharsimi. (2009). Prosedur Penelitian Suatu Pendekatan Praktek, Edisi Revisi V. Jakarta :Rineka Cipta.

Buzan, Tony. (2012). Buku Pintar Mind Mapp. Jakarta : PT. Gramedia Pustaka Utama.

Hadari Nawawi. (2003). Metode Penelitian Bidang Sosial. Gajah Mada University Press. Yogyakarta.

Hyerle, N. David dkk. (2011). Peta Pemikiran Jakarta: PT. Indeks.

Iskandar. (2009). Psikologi Pendidikan. Jakarta: Gaung Persada Pers.

Oemar Hamalik. (1994). Kurikulum dan Pembelajaran. BumiAksara : Bandung.

Purwanto, Ngalim. (1990). Psikologi Pendidikan. PT. Remaja Rosdakarya. Sanjaya Wina. (2006). Strategi Pembelajaran Berorientasi Standar Proses Pendidikan. Jakarta: Prenada Media Group.

Sanjaya Wina. (2011). Strategi Pembelajaran Berorientasi Standar Proses Pendidikan. Jakarta: Prenada Media Group.

Somantri Ating dan Sambas Ali Muhidin. (2006). Aplikasi Statistika Dalam Penelitian. Bandung: PustakaSetia.

Sudrajat Akhmad. (2011). Kurikulum \& Pembelajaran dalam Paradigma Baru. Yogyakarta: Paramita Production.

Sugianto. (2010). Model-model Pembelajaran Inovatif, Surakarta: UNS Pers.

Sugiyono, (2012). Metode Penelitian Kuantitatif dan Kualitatif Dan R \& D, 
Alfabeta, Bandung.

Sudjana.(2012), Statistika II, Edisi Baru, Penerbit Tarsito.

Suryabrata Sumadi. (2004). Psikologi Pendidikan. Jakarta: Rajawali Pers.

Trianto,(2007).Model-Model Pembelajaran Inovatif Berorientasi Konstruktivistik, Jakarta: Prestasi Pustaka.

Yudhawati, Ratna dan Haryanto Dany. (2011). Teori-Teori Dasar Psikologi Pendidikan. Jakarta: PT. Prestasi Pustakarya

Undang-undang UU No. 20 Tahun 2003 Tentang Sistem Pendidikan Nasional. 